\title{
Functional Polysaccharides Blended Collagen Cryogels
}

\author{
Fonksiyonel Polisakkaritler İçeren Kollajen Kriyojeller
}

\author{
Research Article
}

Sedat Odabas

Department of Chemistry, Faculty of Sciences, Ankara University, Ankara, Turkey.

\section{ABSTRACT}

esearches investigate new types of scaffolds for tissue engineering and regenerative medicine applications T to support cell proliferation and growth as well as tissue repair and regeneration. Although, there are several types of polymeric materials and various kinds of preparation techniques are already used today; there is still no consensus on the answer of the question "what is the best scaffold for tissue repair and regeneration?". Cryogels, which is a kind of hydrogels and, cryogelation, which is the technique for cryogel preparation, are rather new for tissue engineering applications. Here in this study, dextran and carboxymethyl cellulose functional polysaccharides blended collagen cryogels were prepared and characterized by chemical, structural and biological evaluations. Results show that, these collagen cryogels with their polysaccharides functional components have proper chemical and thermal characteristics and show good bio and hemocompatibility. Therefore, these cryogels can be used as a candidate scaffold for tissue engineering and regenerative medicine applications.

\section{Key Words}

Collagen, polysaccharides, cryogels, tissue engineering .

\section{Ö z}

\begin{abstract}
A raştırmacılar doku mühendisliği ve rejeneratif tıp uygulamalarında, hücre çoğalması ve büyümesi, doku A hasarının onarılmasını ve yenilenmesini desteklemek için yeni doku iskeleleri araştırmaları yapmaktadırlar. Günümüzde çok sayıda farklı polimerik malzeme ve değişik hazırlama teknikleri kullanılsa da, henüz hangi doku iskelesinin doku tamiri ve yenilenmesi için en iyidir? sorusunun cevabı için bir uzlaşı yoktur. Hidrojellerin bir türü olan kriyojeller ve kriyojel hazırlama tekniği olan kriyojelasyon, doku mühendisliği uygulamaları açısından kısmen yeni sayılırlar. Bu çalışmada, karboksimetil selüloz ve dekstran içeren fonksiyonel polisakkarit içeren kollajen kriyojeller hazırlanmış ve kimyasal, yapısal ve biyolojik değerlendirmeler ile karakterize edilmiştir. Sonuçlar, hazırlanan fonksiyonel polisakkarit birimleri içeren kollajen kriyojellerin kimyasal ve termal olarak uygun özelliklerinin yanında biyo ve kan uyumluluklarının iyi olduğunu ortaya koyulmuştur. Sonuç olarak, bu kriyojeller doku mühendisliği ve rejeneratif tıp uygulamaları için uygun bir aday doku iskelesi olarak kullanılabilirler.
\end{abstract}

\section{Anahtar Kelimeler}

Kollajen, polisakkaritler, kriyojeller, doku mühendisliği.

Article History: Received: Nov 5, 2017; Revised: Jan 22, 2017; Accepted: Feb 02, 2017; Available Online: Feb 20, 2018.

DOI: $10.15671 /$ HJBC.2018.219

Correspondence to: S. Odabas, Department of Chemistry, Faculty of Sciences, Ankara University, Ankara, Turkey. 


\section{INTRODUCTION}

Tiss issue engineering is a scientific perspective that combines cells, biologically active molecules and proper scaffolds, to repair or regenerate the damaged tissues [1]. Scaffolds can act as matrix material to support cell adhesion, growth and proliferation as well as cell differentiation and new tissue formation. There are several kinds of scaffolds that can be used in tissue engineering applications [2]. Some scaffolds can be derived from biological origin such as collagen, hyaluronic acid, silk fibroin. On the other hand, some scaffolds can be produced from synthetic polymers such as polylactic acid (PLA) and poly$\varepsilon$-caprolactone (PCL) or polydimethylsiloxane (PDMS) $[2,3]$. There is still not a consensus on which biomaterial or source origin is the best for tissue engineering applications $[3,4]$. But there is a consensus about what a scaffold should have the properties, such as has no or limited toxicity, excellent biocompatibility, non-immunogenicity and non-carcinogenicity, easy fabrication and having enough stability and mechanical strength [2-5].

Cryogels are kind of hydrogels that have macropores in their structure. Cryogels can be formed via cryogelation technique at below $0^{\circ} \mathrm{C}$ which is based on the principle of forming pores or lamellar structures while expelling water from the surrounding [6]. Today cryogels have found great interest in various fields of applications such as bioseparation, purification, wastewater treatment and some other biotechnological processes [7-10]. In recent years, remarkable studies also showed that cryogels have a potential at tissue engineering and regenerative medicine applications [11-15].

Collagen is one of the abundant natural polymer in entire body and it is the main structural protein in extracellular matrices. Therefore many reports have been published to present that collagen based biomaterials can be candidate scaffolds for tissue engineering applications alone or in blended forms. With its unique fibrillar protein formation and its cell inductive property, collagen can easily support cell proliferation, differentiation and new tissue formation [16-19].
Scaffolds that are used in tissue engineering are mostly cross-linked in their last form. There are various types of cross-linking agent reported in literature $[20,21]$. Among all chemical crosslinkers, glutaraldehyde and formaldehyde are very well-known but highly toxic ones. Moreover, 1-Ethyl-3-(3-dimethylaminopropyl)-carbodiimide (EDC) is also a chemical cross-linker that couple carboxyl or phosphate groups to primary amines and provide zero-length cross-linking. However scaffolds after EDC crosslinking often shows weak stability and mechanical properties. For about a decade, researchers use a technique based on periodate oxidation of carbohydrate sugar groups. Dextran is one of the most biocompatible one among other carbohydrates. Dextran is a hydrophilic branched polysaccharides with $\alpha-1,6$ D-glucopyranose residues and $\alpha-1,2, \alpha-1,3$ and $\alpha-1,4$ side chains in the structure. It can be used for artificial plasma, anti-thrombolytic agent and binder in biomedical applications. Its oxide form - oxide dextran, has been used as biocompatible chemical cross-linker agent to cross-linked the polymer while integrating of the polymer main structure [22].

Cellulose is also a well-known biopolymer. Although, the sole form of cellulose has found limited application in biomaterial field due to its insoluble characteristics in water, its modified forms such as carboxymethyl cellulose (CMC), cellulose acetate, cellulose nitrate have been used in several application such as binding, dialysis system, chromatography, controlled release system as well as some sort of other biomedical applications for decades $[23,24]$.

Here in this study, collagen cryogels having functional polysaccharides components are prepared in blend form and characterized by chemical, structural and biological evaluations. Collagen was used as a main biopolymeric compound as it has superior biological induction property. Moreover, $\mathrm{CMC}$ was chosen to improve cryogel swelling property. Lastly, dextran was chosen to cross-linked and strengthen the cryogel as well as to improve the biocompatibility in its last form. 


\section{MATERIALS AND METHODS}

\section{Preparing Cryogels}

All chemicals were purchased from SigmaAldrich (Germany) and used as instructed unless otherwise stated. Cryogels were prepared as reported elsewhere with slight modifications [14]. Briefly, collagen (from rat-tail) is the basic component of the cryogels so collagen was swollen in acetic acid $(0.1 \% ; \mathrm{v} / \mathrm{v})$ under gentle mixing for about $24 \mathrm{~h}$. CMC solution (5\%; w/v) was prepared from its sodium salt in distilled water. Dextran (MW: 20.000 Da) was oxidized with periodate by catalysis free aqueous reaction which also reported elsewhere [14]. Here, collagen and CMC were mixed with appropriate amount of oxide-dextran (2:2:1; w/w/w) and stirred for $5 \mathrm{~min}$ in room temperature and the solution was then poured into wells and quickly placed into cryostat for $24 \mathrm{~h}$. Samples were then lyophilized and kept $+4^{\circ} \mathrm{C}$ till use.

\section{Characterization of Cryogels}

\section{Biodegradation Properties}

The degradation profiles of the fabricated cryogels were evaluated in an enzyme-free media containing $1 \%$ sodium azide $(\mathrm{w} / \mathrm{v})$ at $37^{\circ} \mathrm{C}$ in a shaking incubator. Evaluation was performed triplicate and samples were weighted prior to evaluation. Analyses were performed gradually with Iyophilized samples in defined time points.

\section{Swelling Properties}

In order to evaluate the swelling properties of the cryogels, samples $(\mathrm{N}=3)$ were soaked into $0.01 \mathrm{M}$ phosphate buffer ( $\mathrm{pH}$ 7.4) at room temperature. All samples were weighted before and after the swelling up to $15 \mathrm{~min}$. The ratios of swelling (SD (\%)) were determined via given equation (Equation 1) where $W_{1}$ and $W_{2}$ represent the dry and wet weight of the cryogels respectively.

$\operatorname{SD}(\%)=\left(W_{2}-W_{1}\right) /\left(W_{1}\right) \times 100$

\section{Chemical and Structural Characterization}

Cryogels were evaluated in terms of their chemical composition, structural, thermal and morphological properties. Thermogravimetric analysis (TGA; (Pyris; Perkin Elmer, USA) was carried out by up to $900^{\circ} \mathrm{C}$ at a heating rate of $10^{\circ} \mathrm{C} / \mathrm{min}$. Crystallography pattern of the cryogels were evaluated by X-Ray Diffractometer (Rigaku D/Max 2200 ULTIMAN, Japan) under nitrogen atmosphere. Samples were scanned in 2 Theta with a scan rate of $5 \% \mathrm{~min}$. Chemical characterization was performed by Fourier Transform Infra Red Spectroscopy (FTIR-ATR; Perkin Elmer, USA) with a frequency range of $600-4000 \mathrm{~cm}^{-1}$. Morphological and structural analysis of the cryogels was evaluated with Scanning Electron Microscopy (FEI Nova, USA) with accelerating voltage of $10 \mathrm{kV}$. Samples were coated with a thin layer of gold prior to analysis. All evaluations were performed in triplicate.

\section{Biological Evaluations of the Cryogels}

\section{Cytotoxicity Assessment}

Possible cytotoxic effects of the cryogels were determined by means of cell viability were determined by well-known indirect MTT assay. Briefly, $1 \mathrm{~cm}^{2}$ samples $(\mathrm{N}=3)$ were soaked in DMEM/F12 culture media supplemented with 10\% Fetal Bovine Serum and 1\% (v/v) antibiotic/ antimycotic solution for about $24 \mathrm{~h}$ at $37^{\circ} \mathrm{C}$ (extraction media). Meanwhile $1 \times 10^{4}$ MG3T3 mouse osteoblastic cells were seeded on 96 well plates. Cells were cultured with $200 \mu \mathrm{l}$ of fresh culture medium and incubated at $37^{\circ} \mathrm{C} ; 5 \% \mathrm{CO}_{2}$ for $24 \mathrm{~h}$. Later on, medium was discarded and $100 \mu$ of extraction media were added to each well except control group. Cells were incubated at $37^{\circ} \mathrm{C}$; $5 \% \mathrm{CO}_{2}$ for another $24 \mathrm{~h}$. After $24 \mathrm{~h}, \mathrm{MTT}$ assay was performed. The absorbance values were measured at $570 \mathrm{~nm}$ with a micro plate reader (Biotek Instruments, USA) and cell viabilities were calculated with respect to control.

\section{Hemocompatibility of the Cryogels}

To assess the hemocompatibility of the cryogels, basic blood compatibility parameters such as prothrombin time (PT), fibrinogen adsorption and hemolytic activity of the cryogels were evaluated. For anticoagulant activity, $1 \mathrm{~cm}^{2}$ cryogel samples $(\mathrm{N}=3)$ were incubated with healthy citrated blood for $1 \mathrm{hr}$. at $37^{\circ} \mathrm{C}$ under gentle agitation. After the incubation, blood plasma and reagents were added in a transparent plastic tube immediately and coagulation times were measured. To 
evaluate the hemolysis, $1 \mathrm{~cm}^{2}$ cryogel samples were incubated with $2 \mathrm{ml}$ citrated blood (1/10 diluted) per tube. Distilled water was used as positive control and PBS was used as negative control. Diluted blood and samples were incubated under gentle agitation for $1 \mathrm{~h}$ at $37^{\circ} \mathrm{C}$. Later on, samples were removed and tubes were centrifuged at $1500 \mathrm{rpm}$ for $10 \mathrm{~min}$. Absorbance of the supernatant was measured at $545 \mathrm{~nm}$ and the percent of hemolysis from each sample was calculated according to following equation (Equation 2).

Hemolysis(\%) = (Absorbance of the scaffold)(Absorbance of negative control)/(Absorbance of positive control) $\times 100$.

\section{RESULTS AND DISCUSSION}

\section{Characterization of Cryogels}

Cryogels are relatively emergent type of biomaterials, which may potentials in tissue engineering and regenerative medicine applications. Here, collagen-oxide dextran-CMC cryogels were prepared. Oxide-dextran act as a biocompatible cross-linker, took apart of the body of the cryogels and cross-linked the entire polymeric blend in its last form.

In a typical tissue engineering application, biodegradable scaffolds can be used according to the need of the application. Here, the swelling and in vitro degradation profile of the cryogels was analyzed and results were given in Figure 1. According to these results, cryogels shows great swelling property over time (nearly $1150 \%$ with respect to its initial dry form by the end of 15 min.) and could degrade entirely at the end of a month. Of course, the degradation time can be adjusted by changing the ratio of oxide-dextran in the structure. As oxide dextran act as cross-linker, changing the ratio of oxide dextran may affect the swelling behavior of the cryogels.

Thermal behavior and thermal stability of the cryogels were assess by thermogravimetric analysis (TGA) and result was given in Figure $2 \mathrm{a}$. According to TGA thermogram, nearly $10 \%$ weight loss by $100^{\circ} \mathrm{C}$ can be corresponded to moisture loss and chemical water in the cryogel. The main weight losses occurred between $100^{\circ} \mathrm{C}-250^{\circ} \mathrm{C}$ and $250^{\circ} \mathrm{C}-550^{\circ} \mathrm{C}$. These findings are similar with the literature $[25,26]$. The final residue after mass decomposition can be associated with ashes and undecomposed material.

According to X-Ray Crystallography spectrum of cryogels that was given in Figure $2 b$, collagen and $\mathrm{CMC}$ shows broad widen peak at around $10^{\circ}$ $30^{\circ}$ that is very compatible with the literature. Moreover, typical broad peaks from dextran are also appeared around same degrees like from collagen and CMC [25-27].

For chemical characterization of collagen/ oxide dextran/CMC cryogels, attenuated total reflection FTIR-ATR spectrum was used by means of different functional groups and bond linkage. FTIR spectrum was depicted in Figure 3. Spectrum of collagen, cellulose and dextran consisting main blend cryogel revealed peaks around $3300 \mathrm{~cm}^{-1}$ that can be associated with $\mathrm{N}-\mathrm{H}$ stretching, amide $\mathrm{A}$ and $-\mathrm{OH}$ stretching. Peaks around $2900 \mathrm{~cm}^{-1}$ can be associated with $\mathrm{CH}_{2}$ stretching and peaks around 1700 to $1640 \mathrm{~cm}^{-1}$ can be associated $\mathrm{C}=0$ stretching of amide $\mathrm{I}$ and $-\mathrm{OH}$ bending. There is also peak around $1580 \mathrm{~cm}^{-1}$ that is associated
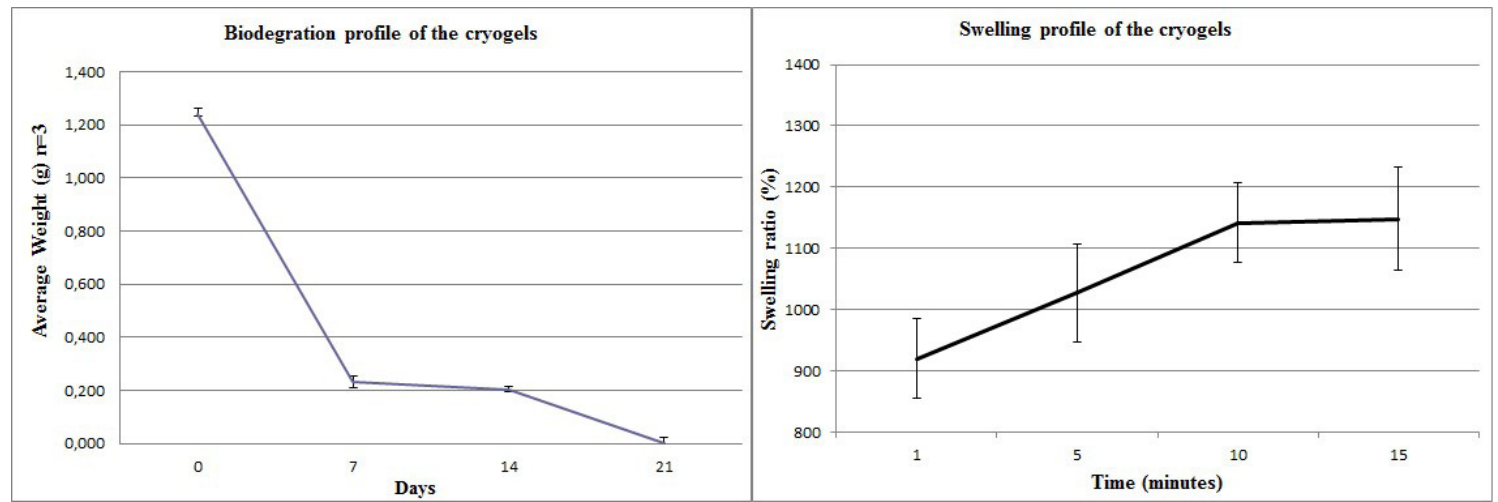

Figure 1. Biodegradation and swelling profiles of the cryogels. 


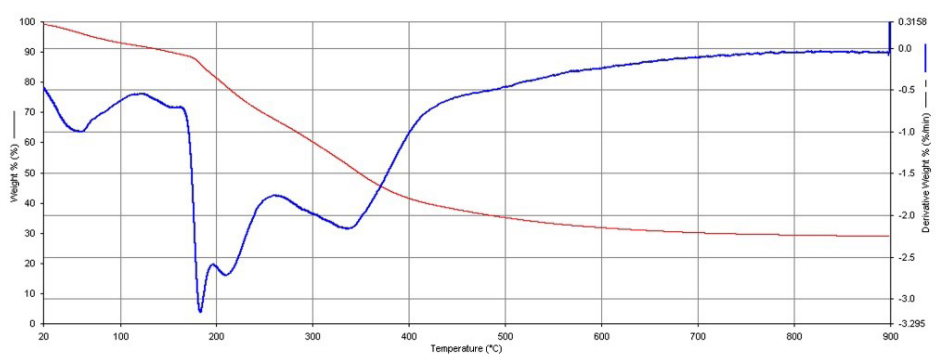

(a)

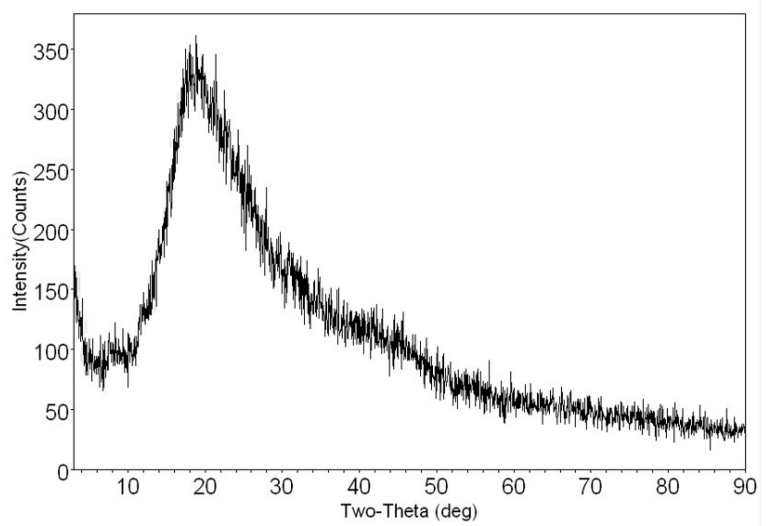

(b)

Figure 2. TGA (a) and X-RD (b) analysis of the cryogels.

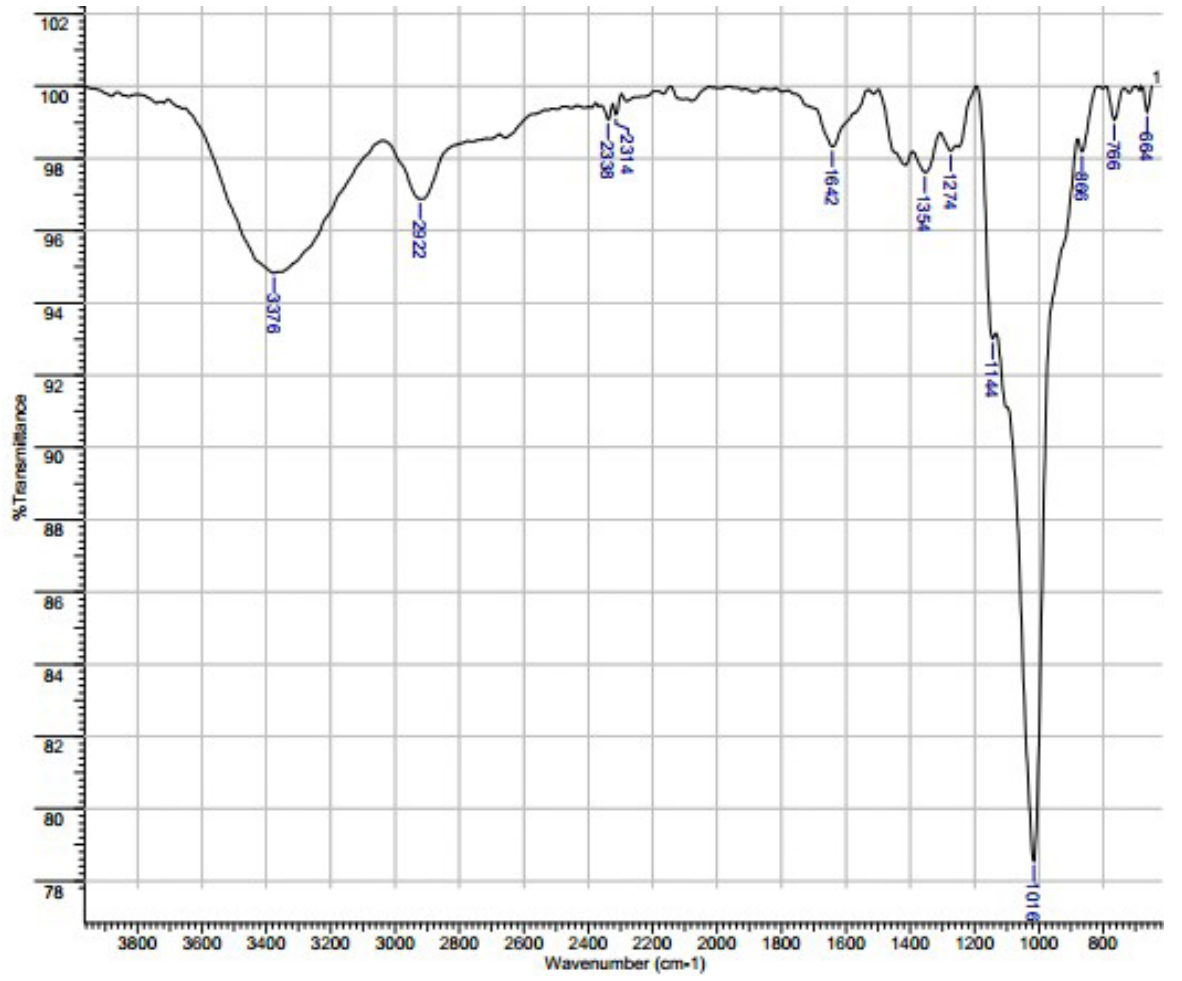

Figure 3. FTIR spectrum of the cryogels. 

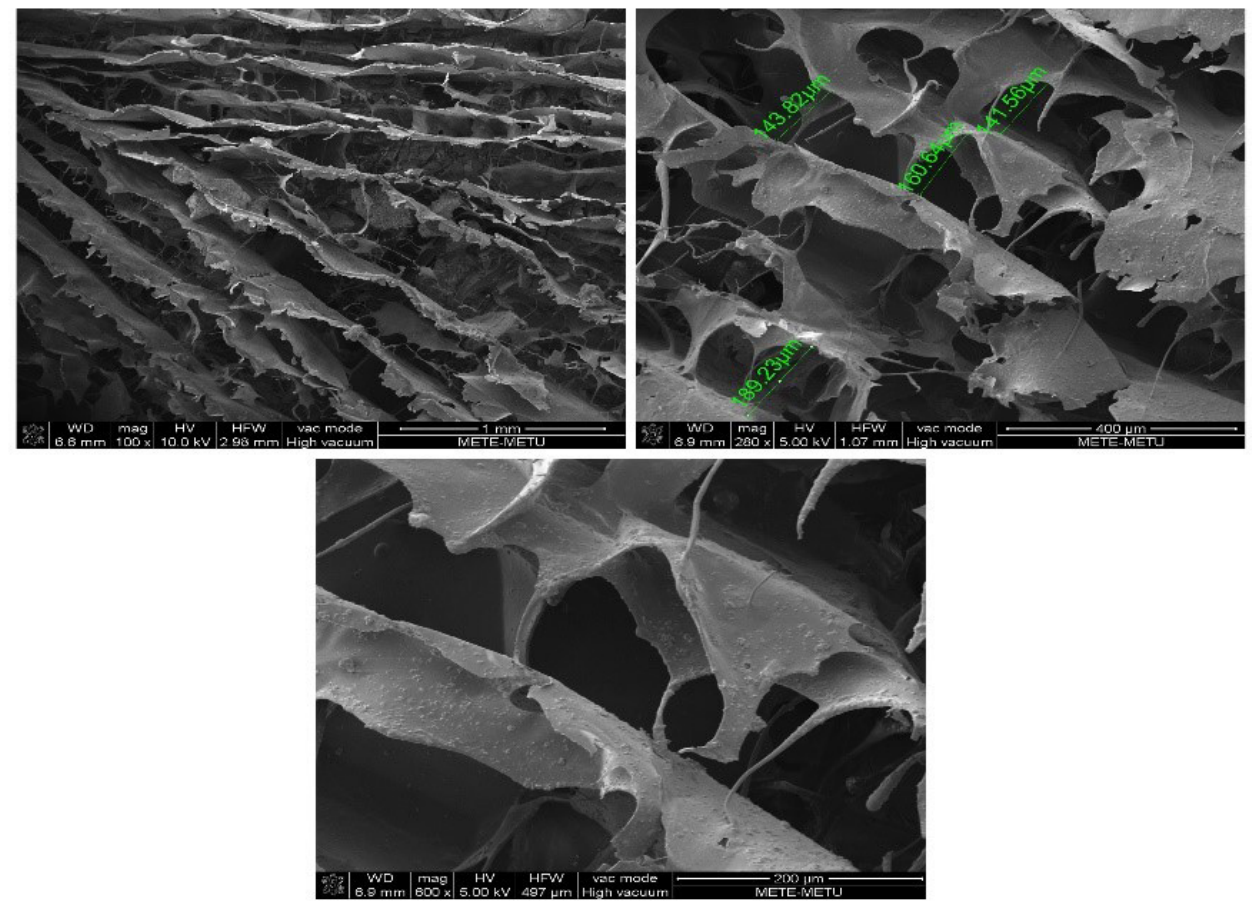

Figure 4. Scanning Electron Micrographs of the cryogels.

with $\mathrm{N}-\mathrm{H}$ bending for amide II. The peaks from $1400 \mathrm{~cm}^{-1}$ to $1000 \mathrm{~cm}^{-1}$ can be associated with deformation of $\mathrm{CH}_{2}, \mathrm{CH}_{3^{\prime}}-\mathrm{OH}$ and $\mathrm{C}-\mathrm{O}$. The all spectrum results shows typical similarities with previously published reports about biopolymer based scaffold $[25,27]$.

Figure 4 shows the SEM images of collagen/ oxide dextran/CMC cryogels. According to these images, cryogels shows anisotropic pore structure and irregular morphology as well as having almost lamellar formation. The pore structure and the morphology is crucial for tissue formation and regeneration. A candidate scaffold should have both macro and micro pores. Micropores are crucial for gas exchange and nutrient diffusion. Macropores on the other hand are crucial for cell attachment and growth. The macropore sizes of a candidate scaffold for tissue engineering applications especially for hard tissue repair should be in the range of 150-300 micron in diameter. The cryogels depicted here have interconnected pores and sheets that have well enough diameters to enable cell attachment and ingrowth as well as possible new tissue formation.

\section{Biological Evaluations of the Cryogels}

Biological evaluations of the cryogels were performed via indirect MTT assay and basic hemocompatibility examination. The components of the cryogels used for this study are already known as biocompatible and have no cytotoxic effect. Therefore, here in this study indirect MTT assay was chosen to determine the possible toxic extracts of forefront residues that can come from the cryogels in its last form. According to the results in Table1, cryogels have shown quite cytocompatible (over $96 \%$ cell viability) with respect to the control after $24 \mathrm{~h}$. This result also means that the degradation extracts of the cryogels show no toxic effects to the cells.

Blood compatibility is also a key determination for tissue engineering and regenerative medicine applications. In addition to the MTT results, cryogels shows also quite blood compatible considering the hemocompatibility results that have also presented in Table 1. Hemocompatibility test parameters such as prothrombin time (PT), fibrinogen adsorption and hemolysis (\%) are coherent with the reference and the control. Hemolysis ratio $(3.38 \pm 0.88 \%)$ is under the 
Table 1. Cyto and Hemo-compatibility of the collagen-oxide dextran-CMC cryogels.

\begin{tabular}{ccccc}
\hline $\begin{array}{c}\text { Collagen-Oxide dextran- } \\
\text { CMC cryogels (\%) }\end{array}$ & Cell Viability*(\%) & $\begin{array}{c}\text { Protrombin Time } \\
(\mathrm{sec})\end{array}$ & Fibrinogen $(\mathrm{mg} / \mathrm{ml})$ & Hemolysis \\
\hline & $96.86 \pm 8.37$ & $11.4 \pm 0.2$ & $2.77 \pm 0.12$ & $3.38 \pm 0.88$ \\
\hline
\end{tabular}

* Cell viability was calculated with respect to the control at the end of $24 \mathrm{~h}$.

** Reference values: Prothrombin time (9.4-12.5 s); fibrinogen (2.00-3.93 mg/mL).

permissible limit of $5 \%$ [28]. Results show that there is no undesirable condition related with the cryogels and cryogels have no significant effect on coagulation pathways.

\section{CONCLUSION}

In this study, collagen was blended with carboxymethylcellulose and dextran functional polysaccharides and scaffolds were prepared by cryogelation technique. Dextran is also act as a biocompatible cross-linker in its oxide form. Results presented here indicated that these biocompatible cryogels can be a good candidate for tissue engineering and regenerative medicine applications.

\section{ACKNOWLEDGEMENTS}

Author thank to Dr. Serhat Odabas, Dr. Batur Ercan, Dr. Handan Sevim, Mr. Atakan Tevlek for their support in analysis.

\section{References}

1. R.M. Nerem, A. Sambanis, Tissue engineering: from biology to biological substitutes, Tissue Eng., 1 (1995) 3-13.

2. S. Yang, K.F. Leong, Z. Du, C.K. Chua, The design of scaffolds for use in tissue engineering. Part I. Traditional factors, Tissue Eng., 7 (2001) 679-689.

3. L.E. Freed, G. Vunjak-Novakovic, R.J. Biron, D.B.Eagles, D.C. Lesnoy, S.K. Barlow, R. Langer, Biodegradable polymer scaffolds for tissue engineering, Biotechnol. 12 (1994) 689-693.

4. B.P. Chan, K.W. Leong, Scaffolding in tissue engineering: general approaches and tissue-specific considerations, European spine journal: official publication of the European Spine Society, the European Spinal Deformity Society, and the European Section of the Cervical Spine Research Society 17 Suppl. 4 (2008) 467-479.

5. S.J. Hollister, R.D. Maddox, J.M. Taboas, Optimal design and fabrication of scaffolds to mimic tissue properties and satisfy biological constraints, Biomaterials, 23 (2002) 4095-4103.

6. V.I. Lozinsky, I.Y. Galaev, F.M. Plieva, I.N. Savina, H. Jungvid, B. Mattiasson, Polymeric cryogels as promising materials of biotechnological interest, Trends Biotechnol., 21 (2003) 445-451.
7. M. Andac, I.Y. Galaev, H. Yavuz, A. Denizli, Molecularly imprinted cryogels for human serum albumin depletion in: Affinity Chromatography: Methods and Protocols, S. Reichtelt, ed., Methods in Molecular Biology Series, volume 1286, pp 233-237, Humana Press, 2015.

8. D. Cimen, F. Yilmaz, I. Percin, D. Turkmen, A. Denizli, Dye affinity cryogels for plasmid DNA purification, Mater. Sci. Eng. Mater. Biol. Appl., 56 (2015) 318-324.

9. A. Kumar, A. Bhardwaj, Methods in cell separation for biomedical application: cryogels as a new tool, Biomed. Mater., 3 (2008) 1-12.

10. M. Uygun, A.A. Karagozler, A. Denizli, Molecularly imprinted cryogels for carbonic anhydrase purification from bovine erythrocyte, Artif. Cells Nanomed. Biotechnol., 42 (2014) 128-137.

11. N. Bolgen, I. Vargel, P. Korkusuz, E. Guzel, F. Plieva, I. Galaev, B. Matiasson, E. Piskin, Tissue responses to novel tissue engineering biodegradable cryogel scaffolds: an animal model, J. Biomed. Mater. Res. A, 91 (2009) 60-68.

12. C.H. Chen, C.Y. Kuo, Y.J. Wang, J.P. Chen, Dual function of glucosamine in gelatin/hyaluronic acid cryogel to modulate scaffold mechanical properties and to maintain chondrogenic phenotype for cartilage tissue engineering, Int. J. Mol. Sci., 17 (2016) 1-22.

13. M.V. Konovalova, P.A. Markov, E.A. Durnev, D.V. Kurek, S.V. Popov, V.P. Varlamov, Preparation and biocompatibility evaluation of pectin and chitosan cryogels for biomedical application, J. Biomed. Mater. Res. A, 105 (2017) 547-556.

14. S. Odabas, G.A. Feichtinger, P. Korkusuz, I. Inci, E. Bilgic, A.S. Yar, T. Cavusoglu, S. Menevse, I. Vargel, E. Piskin, Auricular cartilage repair using cryogel scaffolds loaded with BMP-7-expressing primary chondrocytes, J. Tissue Eng. Regen. Med., 7 (2013) 831-840.

15. A. Sharma, S. Bhat, T. Vishnoi, V. Nayak, A. Kumar, Three-dimensional supermacroporous carrageenangelatin cryogel matrix for tissue engineering applications, Bio. Med. Res. Int., X (2013) 1-15.

16. L. Cen, W. Liu, L. Cui, W. Zhang, Y. Cao, Collagen tissue engineering: development of novel biomaterials and applications, Pediatric Res., 63 (2008) 492-496.

17. P. Fratzl, K. Misof, I. Zizak, G. Rapp, H. Amenitsch, S. Bernstorff, Fibrillar structure and mechanical properties of collagen, J. Struc. Biol., 122 (1998) 119122.

18. L. Ma, C. Gao, Z. Mao, J. Zhou, J. Shen, X. Hu, C. Han, Collagen/chitosan porous scaffolds with improved biostability for skin tissue engineering, Biomaterials, 24 (2003) 4833-4841. 
19. M. Rafat, F. Li, P. Fagerholm, N.S. Lagali, M.A. Watsky, R. Munger, T. Matsuura, M. Griffith, PEG-stabilized carbodiimide crosslinked collagen-chitosan hydrogels for corneal tissue engineering, Biomaterials, 29 (2008) 3960-3972.

20. S. Mavila, O. Eivgi, I. Berkovich, N.G. Lemcoff, Intramolecular cross-linking methodologies for the synthesis of polymer nanoparticles, Chem. Rev., 116 (2016) 878-961.

21. R. Kluger, A. Alagic, Chemical cross-linking and protein-protein interactions-a review with illustrative protocols, Bioorganic Chem., 32 (2004) 451-472.

22. R.A.C. João Maia, Jorge F.J. Coelho, Pedro N.Simões, M. Helena Gil, Insight on the periodate oxidation of dextran and its structural vicissitudes, Polymer, 52 (2011) 258-265.
23. Y.D. Czaja WK, Kawecki M, Brown RM Jr., The future prospects of microbial cellulose in biomedical applications, Biomacromol., 8 (2007) 1-12.

24. N.A. Hoenich, Cellulose for medical applications: past, present, and future, BioResources, 1 (2006) 1-11.

25. B. León-Mancilla, M. Araiza-Téllez, J. Flores-Flores, M. Piña-Barba, Physico-chemical characterization of collagen scaffolds for tissue engineering, J. Appl. Res. Tech., 14 (2016) 77-85.

26. P.R.F.D.S. Moraes, S. Saska, H. Barud, L.R.D. Lima, V.D.C.A. Martins, A.M.D.G. Plepis, S.J.L. Ribeiro, A.M.M. Gaspar, Bacterial cellulose/collagen hydrogel for wound healing, Mater. Res., 19 (2016) 106-116.

27. T. Nagai, N. Suzuki, Y. Tanoue, N. Kai, Collagen from tendon of Yezo Sika deer (Cervus nippon yesoensis) as By-Product, Food Nutr. Sci., 3 (2012) 72-79.

28. J. Autian, Biological model systems for the testing of the toxicity of biomaterials, Polymers in Medicine and Surgery, Springer, Boston, MA, 1975. 